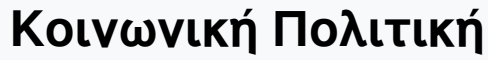

Tóp. 6 (2016)

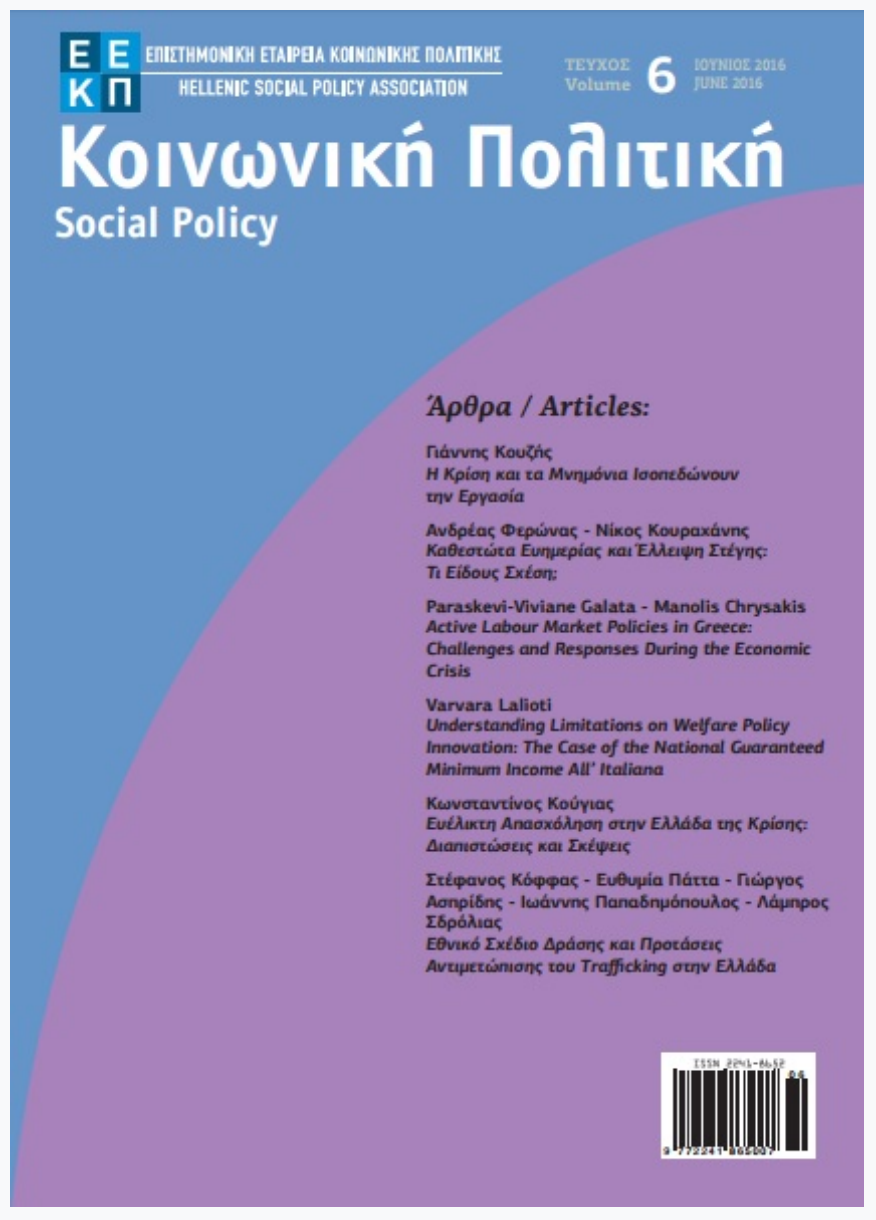

Active Labour Market Policies in Greece:

Challenges and Responses During the Economic Crisis

Paraskevi - Viviane Galata, Manolis Chrysakis

doi: $\underline{10.12681 / \mathrm{sp} .10880}$

Copyright $\odot$ 2016, Paraskevi - Viviane Galata, Manolis Chrysakis

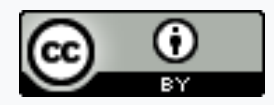

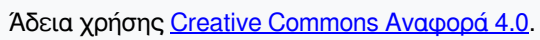

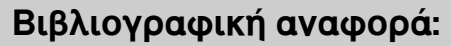

Galata, P. .-. V., \& Chrysakis, M. (2017). Active Labour Market Policies in Greece: Challenges and Responses During the

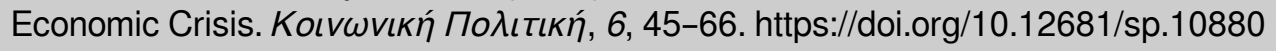




\title{
Active Labour Market Policies in Greece: Challenges and responses during the economic crisis ${ }^{1}$
}

\author{
Paraskevi - Viviane Galata \\ Professor-Advisor, Associated Educational Staff, Hellenic Open University \\ Postdoctoral Researcher, Social Policy Department, Panteion University
}

Manolis Chrysakis

Research Director, National Centre for Social Research

\begin{abstract}
The effects of recession in Greece and the austerity measures promoted in the framework of Economic Adjustment Programmes had a devastating impact in the labour market. Although several reforms have been introduced in the labour market and social protection, doubts are expressed whether the solutions adopted have been effective so far to mitigate the effects of the crisis. This paper aims to explore the role of active labour market policies in Greece during the economic crisis and the necessary conditions to enhance their contribution in reducing the social repercussions of the crisis. The findings from the analysis of existing literature show that there are several challenges for promoting active labour market policies, particularly in a recession, provided that they will not substitute the fundamental guarantees of income replacement and that will be associated with a comprehensive policy of job creation, while preserving the public character and the role of the state that should not be undermined under the pretext of budgetary constraints.
\end{abstract}

Keywords: Active labour market policies, economic crisis, economic adjustment policies, new forms of dual labour market

\section{Пєрí $\eta \psi \eta$}

\footnotetext{
${ }^{1}$ An initial form of this article was presented at the 36th Annual Conference of the International Working Party on Labour Market Segmentation (IWPMS), Long term trends in the world of work and effects of the economic crisis: Policy challenges and responses, Athens: Panteion University of Social and Political Sciences and Hellenic Social Policy Association, 22-24 June 2015.
} 


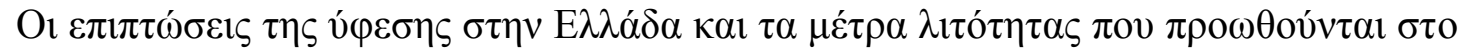

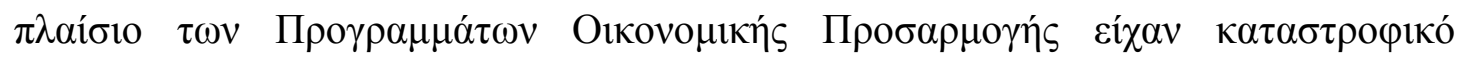

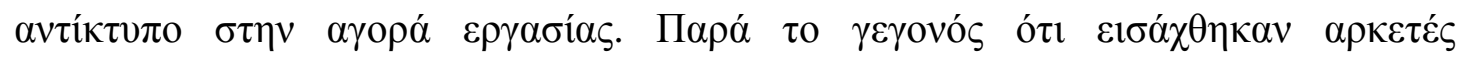

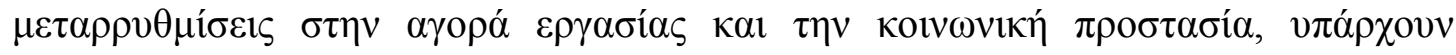

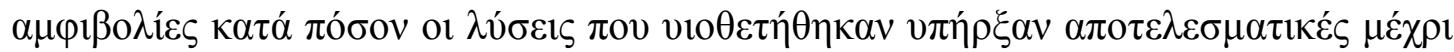

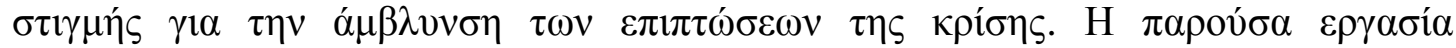

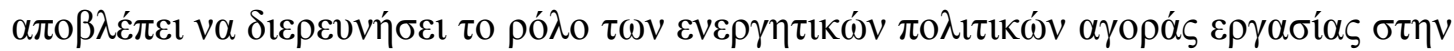

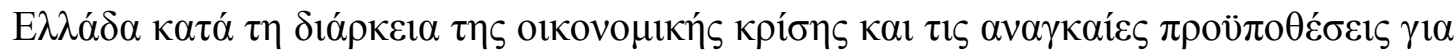

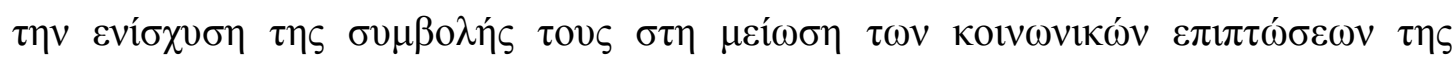

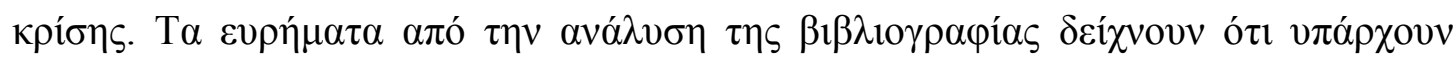

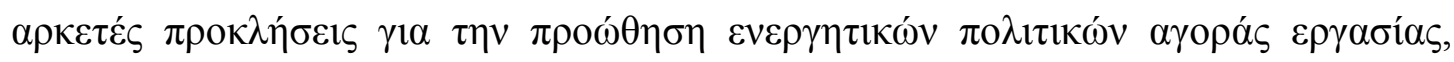

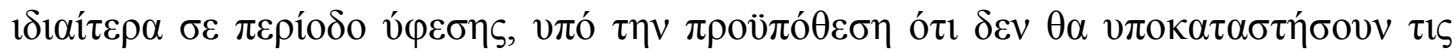

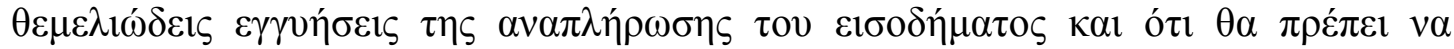

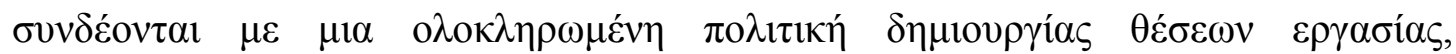

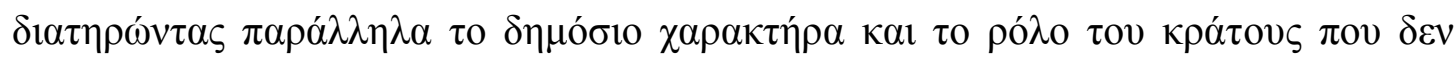

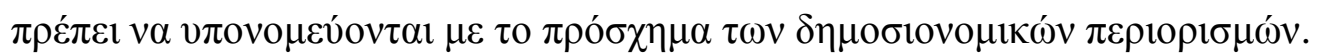

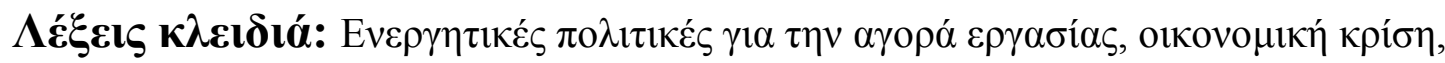

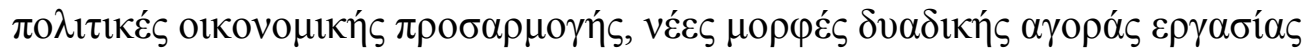

\section{Introduction}

The Greek economy suffered significant macroeconomic changes during the recession since the end of 2009, which have aggravated chronic structural problems in the labour market and have affected large parts of the population. The changes introduced in the Greek labour market to ensure more flexibility and minimize labour costs do not seem to help the country emerge from its economic crisis, while the burden of adjustment appears to have no be distributed fairly (Avram et al., 2013, Matsaganis, 2013, Mitrakos, 2014). The evidence of this unprecedented deterioration of labour market conditions makes the need for better and more effective social support measures even more critical. Therefore, access to employment for the unemployed 
and safety net benefits for the long-term unemployed and the most disadvantaged groups are priority (European Commission, 2013c). Nevertheless, doubts are expressed whether policy responses have been effective so far, if they have contributed to mitigate the immediate effects of the crisis on households and to what extent they could address social concerns and preserve social cohesion under fiscal pressures and cuts in social transfers (OECD, 2014).

In this context, the present paper aims to explore the role of active labour market policies in Greece during the economic crisis and the necessary conditions to enhance their contribution in reducing the social repercussions of the crisis. The issue of active labour market policies is an attractive alternative at this conjuncture, as the current discussion is on the appropriate solutions that could enhance the country's ability to respond effectively to the increased demands of social protection generated by the crisis. In the case of Greece, the limited fiscal capacity of the country along with the existing structural weaknesses of the economy and the welfare state has resulted to selective social policy options, which although justified by the extensive and emergency nature of crisis' social repercussions cannot present convincingly their effective and holistic support. There are serious concerns that selective social policy options introduce new forms of dualism without solving the problems of the vulnerable groups. In addition, the effectiveness of social policy interventions is disputed as they can be used to substitute the fundamental guarantees of income replacement, especially in economic crisis with high levels of poverty and income insecurity. These concerns are even more pronounced due to the restriction of the public character of social policy in view of the required balance between social spending and economic effectiveness and the transfer of competences in the provision of social services in the private sector. Yet, important debates remain concerning the role and effect of active labour market policies in reducing unemployment and raising labour market participation through spending on public employment services, training, employment incentives and direct job creation. Moreover, emphasis is given to the investment in education and training as part of a broad social investment strategy to fight against unemployment, and notably youth unemployment, as well as to bridge the widening skills and education divide. On the other hand, the positive outcomes of active labour market policies cannot easily been achieved in a time of a serious decline of jobs and employment opportunities. 
The paper will explore the role of active labour market policies in Greece during the economic crisis based on secondary research of previously published studies and evaluations on this issue, which will be examined through content analysis and interpreted with the comparative approach of data before and after economic crisis. In the first section, the paper will present the recent theoretical discussion on active labour market policies and their linkages with labour market and welfare policies, on social policy and welfare state responses to social risks under fiscal pressures, as well as on new forms of dualism expressed in social policy and welfare state reforms. Then, the paper will describe in the second section the main characteristics of the Greek labour market, the active labour market policies implemented before or during the economic crisis and their results, as derived from existing evaluation studies and reports. In the third section, the paper will consider OECD countries' experiences on active labour market policies to check and validate the evaluation results of active labour market policies in Greece and to identify the necessary conditions that could ensure their effectiveness. Finally, the paper will summarize and discuss the main findings on the potential challenges of active labour market policies in Greece during economic crisis. Overall, the paper aims to contribute to the deeper understanding that the effectiveness of active labour market policies largely depends on the direction of labour market and welfare state policies towards the selective or holistic coverage.

\section{Theoretical Assumptions on Active Labour Market Policies}

Active labour market policies started to occupy an important role since the 90 s, when the emphasis was placed on the individual responsibility, the more competitive structure of salaries, the adaptation and the strengthening of citizen with the necessary skills through vocational education and lifelong learning (Espin-Andersen, 2002: 4647). This discussion is related to the new European welfare model towards social investment, which differs from the classical models of welfare system developed by Gøsta Esping-Andersen (1990) and Maurizio Ferrera (1996) as it seeks to respond to adaptability, flexibility, security and employability. The focus of this approach, which is put more on "capacitating" interventions than on interventions that compensate, explains fully why the emphasis is given to active labour market policies that enhance 
human capital instead of passive labour policies providing income support for the economically inactive (Begg et al. 2015: 24-25). However, even if active labour market policies appear as an attractive alternative compared to passive policies of income support, there are serious doubts that can be effective as they cannot substitute the fundamental guarantees of income replacement. Moreover, an effective strategy of social investments presupposes the diminution of poverty and income insecurity and, if promoted in real and sustainable terms, can support preventive policies (EspinAndersen, 2002: 48, 73). This issue becomes more complicated in view of recent concerns whether European welfare states will continue to perform their redistributive functions within the pressures on public finances and social spending. Currently, the opinions diverge. On the one side, it is supported that welfare state offers a comprehensive response to social risks and, with the necessary transformations, it can continue to be responsive "as part of the fabric of society and not as an overblown and costly liability" (Begg et al., 2015: 34). On the opposite side, it is stated that the strong social dimension of the European market economy cannot be maintained and, therefore, EU member states will finally converge towards a liberal welfare model (Begg et al., 2015: 34).

The findings of the study in eighteen advanced welfare states, including Greece, show that the social policy responses to the recent economic crisis have varied considerably depending rather on the fiscal capacity of the state than on political and institutional factors (Shahidi, 2015: 659). On the contrary, existing theories of welfare state change give priority to political and institutional explanations for the direction of welfare state during economic crisis - as for instance: the prevalence of existing compensatory mechanisms (the neo-functionalist social compensation hypothesis), the partisan complexion of governments in power leading to different political preferences (the partisan politics hypothesis), the strength of existing welfare measures and the partisan complexion of governments in weaker countries (the constrained partisanship hypothesis), the role of institutions in shaping the contours of welfare state change (the path dependent hypothesis) and the existence of severe fiscal consequences of the economic crisis that can undermine the principles of the welfare state (the fiscal crisis hypothesis) - which cannot in any case explain governments' difficulty to respond to the demand for greater social protection generated by this crisis (Shahidi, 2015: 660-663, 674-676). On the other hand, the restricted coverage 
of increased social needs by the welfare state legalized the transfer of competences in the provision of social services to semi-private voluntary or private organisations, which put the emphasis on the redeployment of public-private relations to respond to the required balance between social spending and economic effectiveness, thereby undermining the public character of social policy that is interrelated to social identity of citizen (Petmesidou \& Papatheodorou, 2008: 11-16).

As far as the Southern European welfare system concerned, according to Papadopoulos \& Roumpakis (2013: 204-206) we need to see its links with the political economy, the production and the employment regime to understand its characteristics as it is distinct from the other types of social-democratic, corporatist and liberal welfare systems. Precisely, the low development of Southern European political economies, which were affected by the EU processes of politico-economic integration, has resulted in "the institutionalization of segmented and residual social programmes and welfare policies" (Petmesidou \& Mossialos, 2006 as cited in Papadopoulos \& Roumpakis 2013: 206). In this segmented welfare system, the family is the main provider of welfare and plays a key role in the reproduction of its institutional arrangements, restricting thus the role of employers and the state. However, the family central role in welfare and its capacity to mobilise economic resources has been undermined in the late 1990s, which marks the transition from securing favourable treatment through clientelistic political relations to fiscal discipline and stricter policy on social spending that brought more pressure to the "familiarization" of welfare costs (Papadopoulos \& Roumpakis 2013: 207-210). Therefore, the crisis of the familistic welfare system was existing before the economic crisis and has been intensified by the crisis subsequent austerity measures leading to a generalized insecurity in both segments of the Greek labour market, i.e. the insiders and protected workers and the outsiders and less protected workers (Papadopoulos \& Roumpakis 2013: 210-213).

However, analysing the linkages among industrial relations, labour market policy and welfare state reforms in view of crisis management, Palier and Thelen (2010: 120121) supports that the institutionalization of new forms of dualism is explicitly underwritten by welfare state reforms. For instance, the reforms introduced in Germany and in France as responses to the economic crisis of 1970s and 1980s, 
aiming at saving core manufacturing economy by reducing workforce and intensifying the work, have institutionalised new types of non-standard jobs without imposing a unified flexibilization for all, thus contributing to the emergence of secondary labour market (Palier and Thelen, 2010: 122-127). A typical example of reinforcing dualism is the increase in state-subsidized jobs in France since the early 1980s, which target unskilled young and long-term unemployed to help them integrated in the society. As characteristically stated, targeted programs within active labour market policies were the favourite policy instrument since the late 1980s "allowing various governments to avoid direct confrontation with the representatives of the more permanent segment of the labor force while allowing them to present subsidization as the price to be paid for job creation in the low-skill service sector" (Palier and Thelen, 2010: 130-131). From late 1980s to 2009 new social policies have been developed in France, which target specific populations and use new instruments aiming to combat social exclusion instead of guarantee income and status maintenance, such as the unemployment degressive benefit paid for a limited amount of time and the active income of solidarity for those entering subsidized low skill, low-paid jobs (Palier and Thelen, 2010: 134-135). Therefore, welfare reforms in Germany and in France have increased the "contributivity" of the benefits, but they lost their redistributive character by reducing the coverage of social insurance, thus reinforcing the gradual dualization of the labour market between workers in the core labour market with occupational insurance/contributory benefits and labour market outsider workers with lower standards and in-work/non-contributory benefits (Palier and Thelen, 2010: 137-139).

In addition, it is supported that the labour force in most European countries is divided into two different groups, defined in terms of job security, compensation and likelihood of receiving on-the-job training. For instance, a large share of temporary contracts coexists with open ended contracts with much stricter employment security, while the young people employed mainly in temporary jobs are the more affected during downturns. Wage pressure is another adverse effect of dual labour markets, which turns to the detriment of temporary workers and in favour of permanent employees. Finally, the amount of training received on the job is considerable less to temporary workers than to permanent workers (Garibaldi \& Taddei, 2013). Similarly, the support of active policies from labour market actors is differentiated according 
their position in the two sectors of the labour market. Following Rueda's work on the insider-outsider theory of active labour market policies, the labour is divided between insiders, i.e. workers in full-time permanent employment and outsiders, i.e. unemployed and workers in temporary or part-time contracts, and their position depends on their exposure to risk of unemployment or their political power. Therefore, if the insiders have very low employment protection increasing the risk of unemployment, they will support active labour market policies and, if the outsiders become members of trade unions increasing their political power, they may support active labour market policies more actively (Vlandas, 2013, Rueda, 2006).

In any case, it is confirmed that there is a deterioration of the quality of jobs during recessions, which calls for specific policy measures targeting the most vulnerable in period of crisis, while there is evidence that active labour market policy spending improves the functioning of the labour market and the following increase in the matching rate improves the total employment (EC-IILS Joint Discussion Paper Series, 2011a and 2011b, García Pérez \& Osuna, 2014). What is important according to Vlandas' findings (2013) is to make a distinguish analysis on what is driving spending on different types of active labour market policies rather than on aggregate spending on active labour market policies. For instance, spending on public employment services is associated with lower employment rates. Spending on job rotation and job sharing is a way to prevent redundancies. Direct job creation involves the use of public funds to directly create jobs in the public or non-commercial sector, while may have a positive impact on wages. Employment incentives and rehabilitation programmes may promote low-wage work and become 'financial subsidies that firms exploit for hiring cheap labour'. Training schemes have the aim of raising human capital and increasing unemployed chances of attaining their preferred employment position (Vlandas, 2013). Therefore, the distinct analysis between different active labour market policies appears to have significant contribution in the discussion on the appropriate solutions to mitigate the negative aspects of economic crisis. However, as Vlandas remarks it is important to take into consideration not only the linkages of active labour market policies with welfare regimes, but also with production systems and national political economies. 


\section{Active Labour Market Policies implemented in Greece during economic crisis}

\subsection{Towards a more aggravated or a more fragmented Greek labour market?}

The Greek economy suffered significant macroeconomic changes during the period 2008-2014, recording a cumulative loss in terms of GDP that exceeded 25\% (Bank of Greece, 2015: 56). Greece continues to face a severe economic recession, which has aggravated the serious and chronic structural problems of the economy and the labour market explaining also why the implications of the crisis were particularly adverse (Cedefop, 2014: 10, 13, Bank of Greece, 2014b: 42, 55). The reforms introduced under the First and Second Economic Adjustment Programmes, agreed in May 2010 and in March 2012 respectively, affected employment protection, wage setting mechanisms and social security and led to deep wage, pension and healthcare cuts, which had a devastating impact in the labour market (Karantinos, 2014, Bank of Greece, 2014a, Cercas, 2014). In fact, the depression has been much deeper than expected, which has induced a fall of employment to $53.3 \%$ and a dramatic rise in unemployment affecting more than $27 \%$ of the labour force at mid-2013 that remains at the high level of $25 \%$ even after the moderate decline since 2013, as well as job losses of around 1 million from 2008 to early 2014 (European Commission, 2015b: 14, Karantinos, 2014, OECD, 2013). The income losses, the high unemployment and the lack of a well-designed social safety net reflect the unprecedented deterioration of labour market conditions across large parts of the population (OECD, 2014, Cercas, 2014), while despite the improvement of tax and benefit reforms targeting progressively high incomes, the burden of adjustment has been uneven as the emergency property tax, the cut in unemployment benefits and the changes in the personal income and property taxation have affected people with lower incomes (OECD, 2016: 10-14, Leventi, Matsaganis, 2016: 13-14).

The young people aged 15-24 are the more affected by the highest unemployment rates, along with the young women and the individuals with low and medium levels of educational attainment. Youth unemployment of this age group reached exceptionally high levels at $52.4 \%$ in 2014 with obvious difference from unemployment rates of other age groups in the workforce (European Commission, 2014c: 25, Ministry of 
Finance 2015: 11). Unemployment among young people aged 20-29 also remains high, although it seems that active employment policies and legislative changes from 2012 to 2014, which allowed the recruitment of young people with lower wages and more flexible forms of employment, have helped to reduce youth unemployment from $47.4 \%$ in 2013 to $44.2 \%$ (Bank of Greece, 2015: 70). The unemployment problem is particularly acute for young people who are neither in employment nor in education and training with rates having increased for 15-24 year olds to above 20\% (European Commission, 2014c: 25, 48). Therefore, the rates of structural unemployment are high and have been aggravated by the crisis (Karantinos, 2014). There is also a serious increase in the unemployment duration, with one in two unemployed workers having been without a job for more than two years and one in five without a job for four years or more (ILO, 2014). Albeit an increase of 11.65 percent has been recorded to salaried employment between 2013 and 2014, one in every five employees are in parttime employment or shift work, while undeclared work and uninsured employment has been aggravated by the economic crisis (ILO 2014).

According the overview of labour market reforms enacted between January 2008 and June 2013, Greece's changes were mostly focused on reducing the generosity of unemployment protection and the strictness of employment protection, while policy reforms in relation to the Greek welfare system have been enacted by reducing established levels of social protection. (Shahidi, 2015: 665-667, 674). Major labour market reforms enacted in Greece over the period 2010-2013 were focused on reducing labour costs and social security contributions, minimizing collective agreements' protection and augmenting wage flexibility, reducing and freezing minimum wages, reforming the minimum wage framework, reducing maturity allowances, broadening the types of temporary work, extending part-time shift work, facilitating working time arrangements, reducing employer-paid contributions, as well as relaxing the conditions for dismissal and the thresholds for collective dismissal (European Commission, 2014b: 47-49, Ministry of Labour, Social Security and Welfare, 2014). In a nutshell, austerity measures and structural reforms in the labour market and welfare state are associated with the wage-setting and employment regimes points towards labour market deregulation and minimalist protection, while social security reforms, especially if combined with the long-term consequences of depression-level unemployment, point to residual social protection (Karamessini, 
2015: 1-2, 47-48). Overall, the economic crisis caused a shock in Greece resulting in serious remuneration and jobs cuts, restrictions in pensions rights and welfare benefits, and sharp labour market reforms, which constitute a considerable effort towards welfare retrenchment existing, though, before the convergence of the national economy within the European Union (Zartaloudis, 2014: 430).

There are no doubts that impoverishment during the crisis and under austerity affected large parts of the population, including not only low-income individuals and households but also the various social strata of the 'middle class', as well as selfemployed and public or private sector employees hit by taxes increase and wage cuts up to 30 and 40 per cent (Karamessini, 2015: 34-35). That's why, it is supported that the crisis subsequent austerity measures have led to a generalized insecurity in both segments of the Greek labour market, i.e. the insiders and protected workers and the outsiders and less protected workers (Papadopoulos \& Roumpakis 2013: 210-213). However, the above labour market reforms and the data on flexible forms of youth employment, part-time and shift work, undeclared work and uninsured employment show that there is an increased polarization between standard and non-standard (e.g. temporary, part-time) forms of employment. Although the reforms had little effect on the creation of temporary employment, they favoured the use of part-time and intermittent employment and there has been a deterioration in the quality of temporary and part-time employment (ILO, 2014). In addition, it seems from the following sections of the paper that the selective programs of active labour market policies intensifying during economic crisis contribute to the gradual dualization of the labour market (Palier and Thelen, 2010: 137-139).

\subsection{Active Labour Market Policies before economic crisis}

Greece maintained for a decade its long-standing model of state intervention in economic and social activities, which along with low taxes revenues, pay rises, generous pensions, early retirement schemes and low efficiency of the public sector led during the 1980s to high public debt, deficits and sluggish growth (Zartaloudis, 2014: 433-435). During the period before economic crisis from 2000 to 2007, the main characteristic was the rapid rise in economic activity without any expansion and diversification of the production base, thus, leading to a distorted growth model and 
chronical imbalances that have not been adequately addressed for many years (Bank of Greece, 2014b: 12-13, 22, 42). Similarly, the Greek welfare state was suffering from substantial weaknesses at the onset of the crisis (Karamessini, 2015: 6). In addition, public deficits and indebtedness because of a significant expansion of earnings-related schemes and clientelistic-particularistic arrangements, led to the retrenchment and rationalisation of social policy in the 1990s with very few attempts to tackle major issues such as the blurred line between social insurance and assistance, the absence of a safety-net (Petmesidou and Guillén, 2015: 7-10).

In this context, the implementation of active labour policies relied almost exclusively on European structural funds and, mostly the European Social Fund, for the financing of public services, public works and vocational training, as well as for the development of EU inspired social policy, such as activation through Public Employment Services or gender equality policies (Zartaloudis, 2014: 432, OECD, 2016: 59). A large part of active labour policies is occupied by lifelong learning policies, aiming at combating social exclusion through training programmes and/or promotion to employment for the inclusion of the unemployed. However, they were characterised until the mid-1990s by the lack of central planning and coordination, the wastage of European resources and the extensive privatisation, which questioned the aim and the mission of active labour market policies against unemployment and social exclusion. (Prokou, 2011: 207, 219-222).

By their scope, active employment policies are selective policies as concentrated to specific social groups, such as young people, women, long-term unemployed, migrants and other vulnerable groups, to increase their employment opportunities and to improve their income perspectives (Dimoulas - Michalopoulou, 2008: 27-30). For instance, during the period 2000-2006, the aim of active labour market policies was focused on the prevention of long term unemployment, the support and encouragement of unemployed to employment, the protection of equal opportunities for access to the labour market and especially for those threatened with social exclusion., the improvement of the access and participation of women in the labour market and the upgrading workers' qualifications and services of the public sector. During that period, there were 642.103 people benefited for relevant programmes for the promotion of employment, vocational education and training, subsidized 
employment for the creation of new jobs or the acquisition of practical experience and the promotion of equal opprortunities through childcare or elderly care structures (Diadikasia, 2014: 28-30).

Furthermore, during the previous programming period 2007-2013 a vast array of active interventions has been implemented to support employment, from which more than 1 million persons benefited at a cost of approximately $€ 3.7$ billion. These interventions have been implemented in the framework of the National Reform Programme for Human Resources, which provides (Ministry of Labour, Social Security and Welfare, 2014):

(a) Subsidised employment through local programmes of employment support, subsidised contributions to employers for hiring unemployed, hiring subsidies to employers, training vouchers for unemployed, public works programmes, subsidies for start-ups

(b) Training programmes for unemployed, vocational training, training vouchers

(c) Programmes of companies' structural adaptations including training of workers

(d) Programmes of social integration through local programmes of job creation and social integration for vulnerable and the National Network against Poverty

According to the evaluation of active policy interventions carried out in the middle of the programming period, the aim of subsided programs for the creation of new jobs or the creation of new companies was selective, reserving a preferential treatment for women, young people and long-term unemployed through quotas in the positions or a higher subsidy for certain categories of unemployed. At that period, these programs seem to function more as a universal employment support programs than selective ones. However, there are serious doubts whether active employment policies contribute to the increase of the participation rate, as few participants were active as unemployed and others were inactive. Also, the dead weight of programs aiming at the creation of subsidized new jobs (50-56\%) or of new companies $(60 \%)$ is very high, which demonstrates that these programs contribute mainly to the support of employment than the promotion to employment of groups with difficulties to enter the labour market or to the enhancement of an existing initiative of entrepreneurship. Finally, the sustainability of new jobs is not evident as it is the case for new enterprises (EEO Group, 2012: 11-.15). 
An additional characteristic deficiency of the period before crisis is the fragmentation of the evaluation of active employment policies and the subsequent difficulties to monitor their implementation. Besides, there are some general remarks on the characteristics of active employment policies that conclude on the lowest spending on labour market interventions in Greece between $2000-2006(0,46 \%$ to $0,9 \%)$ compared to EU-27 average (1.5\% to $2.2 \%$ ) and the subsequent low participation number of beneficiaries. As for the internal structure of the expenditure on interventions in the labor market, the domination of employers' subsidy policies is clear, while expenditure on employment services throughout the period 2005-2009 was extremely low reaching only $2 \%$ of total expenditure on labor market interventions (EEO Group, 2012: 16-22).

Furthermore, the findings of a qualitative research on the effect of Integrated Interventions, implemented during 1994-1999 with the aim to combat unemployment through a combination of professional orientation, vocational training, employment subsidies and counselling, show that the unemployed participants constitute a specific category of labour market's supply, which is constructed and operates depending the supply and demand of subsidised employment. In fact, the Integrated Interventions didn't succeed in implementing a mainstreaming policy for the less favoured groups of unemployed facing difficulties in entering the labour market. On the contrary, these interventions favored the unemployed who had already skills and, therefore, comparative advantages in the labour market (Dimoulas - Michalopoulou, 2008: 43$45,152-153)$.

Overall, the problems identified in the design, implementation and management of active employment policies along with the economic crisis made necessary to redesign these policies. It's worth mentioning that the specific targeting of policies to vulnerable groups that are not in employment and the selection of programs towards employment maintenance, creation of new jobs and vocational training shape the new philosophy of active employment policies in the period of economic crisis (EEO Group, 2012: 23-25).

\subsection{Active Labour Market Policies during economic crisis}


Policy recommendations to cope with the social cost of the crisis indicate the urgent need for more inclusive economic growth to reduce poverty and inequality and boost employment in the short term, including a comprehensive social safety net, better targeted social programs, effective benefit system and expansion of active labour market policies along with guaranteed minimum income (OECD, 2016: 11, 28-29, Jessoula et al., 2015: 23-29). In particular, the priority in late 2013 was to deal with the very high unemployment rate through some key active labour market policies, based on short-term and temporary public work programmes with 50,000 positions mainly for the long-term unemployed, and subsidised internships of 45,000 young jobseekers with private sector employers. Additional reforms in the welfare system provide the revision of various existing benefits to increase the effectiveness of social welfare spending and ensure the targeted support of vulnerable groups with the strongest needs of income support, the tapering of unemployment insurance benefits, as well as the development and integration of the guaranteed minimum income scheme with other social benefits and services (European Commission, 2013b and 2014b: 50-51, OECD, 2016: 57-58). As far as labour market policy concerned, the strengthening of activation programmes (training voucher programs for access to the labour market, public benefit employment schemes) is foreseen to tackle high unemployment with emphasis on their effects in promoting employment, along with the improving of the labour inspection system and the condition access to unemployment benefits on stricter obligations for participation in training and employment service programmes (OECD, 2016: 59).

In this context, the upgrading and expansion of vocational education and apprenticeships is crucial to improving the transition from education to employment and to foster sustainable employment (European Commission, 2015b: 15). To this end, Greek authorities has to pursue a detailed implementation plan for the modernisation and expansion of vocational education and training, and the increase in the provision of apprenticeships, including the establishment of a quality framework and a monitoring mechanism to develop local partnerships, the encouraging of closer employer engagement and private-sector funding in vocational education and training, and the effective matching of vocational education and training with the needs of the labour market (European Commission, 2014b: 48). The Memorandum of 
Understanding for a three-year ESM programme for Greece dated on 19 August 2015 provides specific requirements for the modernisation and expansion of vocational education and training. Subsequently, the National Strategic Framework for upgrading vocational education and training (VET), recently presented by the Ministry of Education takes into consideration the perspectives of the Greek economy, the labour market data and the medium term projections on skills needs and concludes to the vision for upgrading vocational education and training, which is structured in three pillars: (i) strengthening the social role of VET in order to reduce social inequalities, (ii) enhancing the working role of VET and (iii) linking VET with the overall development planning of the country (Ministry of Education, 2016).

In the last quarter of 2014 , there have been urgent initiatives within active labour market policies in order to implement targeted actions in favor of the most affected by unemployment and the vulnerable groups, which include (Ministry of Labour, Social Security and Welfare, 2014):

- Integrated programmes for 8.000 unemployed graduates that provide continuing vocational training in the fields of generic skills, job search skills, entrepreneurial and ICT skills, practical training in private firms and counseling services.

- Training voucher for 38.000 low skilled unemployed workers aged 29-64, which provides theoretical training, practical training in enterprises, as well as counselling and guidance services in construction, waste management and ICT.

- Subsidies to employers in order to hire $\mathbf{5 . 0 0 0}$ unemployed workers for 12 months.

- Public works programmes addressed to 50.000 long-term unemployed persons.

- Specific programmes of Vocational Training for 16.000 young unemployed aiming at the reinforcement of skills in specialisations of cutting edge sectors of the Greek economy.

- Regional mechanisms to support the development of Social Cooperative Enterprises.

In addition, a National Action Plan to implement "Youth Guarantee" in Greece has been elaborated to provide a coherent set of actions targeted to young unemployed and not in Education, Employment and Training (NEETs), which include activation, apprenticeship, traineeship or education, support of entrepreneurship and integrated 
interventions of job search assistance, training, counselling and job offer (Ministry of Labour, Social Security and Welfare, 2014).

Concerning the evaluation of active labour market policies that have been implemented in Greece, it's worth mentioning that evaluation studies are regularly commissioned by the Greek Management Authority for European Social Fund and the Management Authorities of relevant ministries and conducted by external contractors, such as independent experts or private consulting firms and research institutes. However, these evaluations are mainly focused on the implementation or measuring of success of adopted policies and do not provide clear insight to policy making on the design of new policies and on what works and why. Moreover, an operational system for the on-going internal evaluation of ALMPs schemes, as a core service offered by the Greek Public Employment Service, is not yet in place (Chrysakis, 2012). Most of the active labour market policies implemented recently to tackle the effects of the crisis are not evaluated yet, while past evaluations provide little insight due to the different labour market conditions (Karantinos 2015).

During this period, three evaluations on programs of active labour market policies have been conducted. The first evaluation concern the harmonisation of family and professional life with possible results on the employment and maintenance of job positions. The second evaluation was focused on local actions of social inclusion for vulnerable groups, which strengths were related to the individualised approach and support, the regular information, the development of social skills, the training and the networking. Finally, the evaluation of the program of Voucher Entry to the Labour Market has been conducted on the basis of quantitative research with a web survey and a qualitative research through seven focus groups with all actors involved. The program of Voucher Entry to the Labour Market implemented during 2014 for 35,000 unemployed young people aged up to 29 years has been evaluated and resulted in the formulation of concrete recommendations to ensure better targeting and to avoid eventual substitution of employers by the beneficiaries of the program. It is suggested to award more points in the age group 25 to 29 which is at a disadvantage position in the labour market due to longer duration of unemployment. Further restrictions are needed to discourage companies to make continuous use of the voucher program to cover their needs in labour force. Attention should also be paid to preventing possible 
replacement of employers by the program's beneficiaries, while stricter conditions should be adopted for the training providers. Finally, it would be useful to follow a certification procedure for the skills acquired by the beneficiaries during the voucher program (Karantinos et al., 2015: 278-279).

Despite the lack of regular and comprehensive evaluation studies on ALMPs, some broad conclusions can be drawn by the existing literature for the period during the economic crisis (Karantinos, Chrysakis, Balourdos, Mouriki, Soulis, Galata, Petraki and Kostaki, 2013, Karantinos 2014):

- The available indicators show that the amounts dedicated to active labour market policies are particularly low, as labour market policy expenditure seems to rely more on passive measures than on actives ones.

- The most important weaknesses of active labour market policies in Greece concern the little connection with the needs of the labour market and the lack of evaluation.

- Concrete policies should be implemented to address the structural labour market problems and improve the matching of job seekers with new vacancies, so as to avoid the conversion of unemployment from cyclical to structural, i.e. permanent.

- Future developments in the Greek economy will also depend on structural policy measures, namely by improving the quality and efficiency of education as well as the development of skills in areas that can become new sources for growth.

- Greater emphasis should be made on activating the unemployed, especially youth and women. Job-search training should be the top priority in individual action plans along with job counseling services.

- Existing employment subsidies should be better targeted to the most disadvantaged youth, such as early school leavers and individuals who have not been in employment, education or training for a long-term.

- The introduction of apprenticeships and the planned VET reform with strong links of the educational and training system with the labour market are essential.

- Stronger emphasis should be placed on the weak areas of active labour market policies in Greece, such as mechanisms for early identification of skill needs, quality assurance and management of schemes, guidance and counselling services. 
- Main priorities in combating the effects of the crisis should be policy measures for young people, subsidizing employment and self-employment, active inclusion of people at risk of social exclusion, local public-spirited programmes, development of social economy, continuing vocational training and strengthening of rehabilitation services.

\section{Active Labour Market Policies in OECD countries}

Active labour market policies occupy an important role in the OECD and EU policies that have been developed since the 1990s to improve employment and labour market performance and encompass: "all social expenditure (other than education) which is aimed at the improvement of the beneficiaries' prospect of finding gainful employment or to otherwise increase their earnings capacity" (European Commission, 2015). More specifically, active labour market policies include public employment services (job placement, counselling and vocational guidance), labour market training for unemployed and employed adults, youth measures referring to training and employment programmes and apprenticeship, subsidised employment (hiring subsidies to private-sector employers to hire unemployed, assistance to unemployed persons to start their own business and direct job creation), as well as measures for the disabled including vocational rehabilitation training to enhance employability and work programmes which directly employ disabled people (Martin \& Grubb, 2001 • Eurofound, 2010). On the other side, passive labour market measures include unemployment benefits to the unemployed and early retirement benefits (Martin \& Grubb, 2001 • Eurofound, 2010).

A mix of passive and active labour market policies is generally used in order to counter higher unemployment rates. Yet, expenditure on active labour market policies is indeed more likely to reduce unemployment with a lower fiscal cost as savings may be generated on passive policies. However, some Member States with high unemployment spend relatively small shares of their GDP on labour market services and active measures (notably Bulgaria, Slovakia, Lithuania, Latvia, Croatia and Greece), although it may be worthwhile to shift some spending to activation measures (European Commission, 2015). Across the EU, labour market policy measures 
account for $1.6 \%$ of GDP with a ratio of approximately 2:1 in expenditure between passive and active measures. Despite the variety in the structure of ALMP spending over Member States, training accounts for the biggest share of expenditure at nearly $40 \%$ and employment incentives account at $24 \%$ of expenditure. Supported employment and rehabilitation, as well as direct job creation occupy a significant share of funding at $16.1 \%$ and $13.4 \%$ of expenditure respectively (Eurofound, 2010). Nonetheless, total expenditure on active labour market policies has been falling in the EU-28 since 2010, despite the severity of the labour market challenge. On the other hand, even when active labour market policies spending was increasing during the crisis (2007-2010), the activation support was not commensurate with the labour market needs generated by the crisis (ILO 2015: 28).

Thus, a major question is raised concerning the impact of active labour market policies in reducing unemployment and raising labour market participation. The analysis of the effects and the contribution of active labour market policies in labour market performance is based on the existing literature related to the evaluation of the different forms of active labour market policies and programmes. The evaluations that have been performed measure either the impact of training and job assistance programmes on individuals' employment and earnings or the net effects of subsidised employment programmes on aggregate employment and unemployment by estimating “dead-weight", "substitution" and "displacement" effects (Martin \& Grubb, 2001).

Following the findings of this analysis, we can come to the following conclusions:

- Employment services are the most cost effective intervention (Cazes, Verick \& Heuer, 2009) and has positive outcomes according to evaluations in some countries, notably Canada, Sweden, the UK and the US (Martin \& Grubb, 2001). The mix of measures involving job matching, counselling and guidance and private sector employment subsidies are more likely to have positive outcomes (Eurofound, 2010). Therefore, counselling, job-finding incentives and job-search assistance programmes are effective if they are combined with increased monitoring of the job-search activity and enforcement of the work test (Martin \& Grubb, 2001).

- Training programmes have a 'modest likelihood' of having a positive impact on post-programme employment (Eurofound, 2010), but they can have positive 
impacts, particularly when conducted in the workplace (Cazes, Verick \& Heuer, 2009). Findings show that training programmes tend to be among the most expensive active measures, while only some training programmes work (Martin \& Grubb, 2001), such as vocational trainings that need to be based on a more targeted and market-oriented function (Duell, 2012). The effectiveness of training programmes can be maximised if they are small scale, built with mainly on-thejob content and well targeted to the specific needs of unemployed and employers (Martin \& Grubb, 2001).

- Youth programmes have $40 \%$ to $60 \%$ lower probability of generating positive outcomes than those targeted at older age groups (Eurofound, 2010). Training programmes, wage subsidy measures and direct public sector job creation schemes are not effective for disadvantaged youths, even they have been particularly popular in many European countries. Effective programmes for disadvantaged youths should combine: (a) close link to the local labour market and jobs, (b) mix of academic education, occupational skills and on-the-job training and (c) a range of supporting services, tailored to their needs (Martin \& Grubb, 2001).

- Employment subsidies do not have a favourable impact, as for instance public works programmes can be effective as a safety-net but usually do not lead to better employment opportunities and entrepreneurship incentives are appropriate for a small segment of the population (Cazes, Verick \& Heuer, 2009). Even if the impact of these programmes is greater than training programmes or job creation measures, their net employment gains are very small and they present large deadweight and substitution effects. On the other hand, the goals of these programmes to keep individuals in contact with the world of work or to provide the long-term unemployed with jobs may be important (Martin \& Grubb, 2001). In any case, subsidized employment need to be run on a smaller scale, combined with other ALMP measures like training (Duell, 2012), targeted to particular groups of unemployed and closely monitored (Martin \& Grubb, 2001).

- Direct public sector employment programmes are not effective in helping unemployed people to get permanent jobs and they may actually worsen employment prospects (Eurofound, 2010). These programmes should be implemented exceptionally for a short duration and targeted to the most 
disadvantaged, while temporary employment programmes in the public sector can be used particularly in a recession when vacancies are scarce (Martin \& Grubb, 2001).

- Interactions between active measures and unemployment benefit systems can have significant effects on work incentives for the unemployed and on the wagesetting behaviour of workers and employers. Furthermore, activation strategies with additional perspectives to intensify job search can have impact on transitions to employment for people receiving unemployment benefits (Martin \& Grubb, 2001).

Additional findings from evaluations reveal some particular aspects that can influence programme effects, such as:

- The type of programme itself is the primary factor determining the success of labour market outcomes, rather than contextual factors such as business-cycle timing or institutional labour market features (Eurofound 2010).

- Significant positive employment impacts are much more likely to be identified two or three years after programme participation (Eurofound 2010).

- Comprehensive assessments should assess outcomes against unit costs (Eurofound 2010), which can turn the estimated programme effects into negative (Martin \& Grubb, 2001).

- Comprehensive assessments should not be limited to output measures related for instance to the number of placements in employment, but calculate economic efficiency measures based on short-term expenditure and outcomes (Collins, 2012).

Finally, the analysis of studies on policy decisions adopted by governments in 79 OECD and non-OECD countries, since the beginning of the economic crisis, shows that training is the most commonly used active measure in high-income countries (27 countries), followed by work sharing (24 countries), increased resources for public employment services including job search assistance measures (20 countries), and subsidies (20 countries). The least-implemented intervention in this group of countries is public works programmes (5 countries) due to its limited effectiveness. Moreover, 17 high-income countries have made changes to unemployment benefits schemes 
based on extensions of coverage and broader eligibility criteria (Cazes, Verick \& Heuer, 2009). Similarly, the most utilized policy response in the middle-income group is training (with 25 countries) followed by job search assistance, entrepreneurship incentives and public works programmes. Interestingly, 11 of these countries are using a reduction in working hours to support employers in response to the downturn, though not all these interventions are subsidized. There are far fewer low-income countries implementing such policies in response to the crisis, focusing on entrepreneurship incentives and training. Overall, the use of labour market policies in response to the current crisis is declining, which reflects the financial and technical constraints hindering the response of these governments (Cazes, Verick \& Heuer, 2009). On the other hand, active labour market policies present some challenges despite the significant decline of jobs and employment opportunities. For instance, training has obvious attractions in a downturn, as it enhances social contact for the unemployed, responds to existing skill gaps (Eurofound, 2010) and address the growing divide between the educational 'haves' and the 'have-nots' for reasons of social equality and for economic efficiency (Friends of Europe, 2015a). Moreover, short-term complementary active labour market policies are needed to ensure that individuals have the right skills to take up the jobs created, while focus should be given on job search assistance and training as well as on as training programmes accompanied by specific services of matching skills to sector needs, which are among the most effective active labour market policies. Furthermore, the reinforcement of active labour market policies, along with a targeted combination with passive policies and adequate income support to all jobseekers, is needed to ensure the necessary support to the most vulnerable (ILO, 2015). Besides, active labour market policies should be associated with job creation, while a comprehensive policy to boost job creation is absolutely needed to tackle the effects of the crisis (ILO, 2014).

\section{Conclusion}

From the above analysis, the need to protect the unemployed and the most disadvantaged groups from the negative effects of the prolonged economic recession in Greece became clear. This requires undoubtedly well-designed structural policy solutions, more effective social support measures and safety net benefits. In this 
context, the role of active labour policies is appearing attractive as they can contribute to the better functioning of the labour market, ensure that workers remain attached to the labour market and provide unemployed with the right skills to take advantage of emerging jobs. Also, the effect of active labour market policies in the mitigation of the crisis' social consequences can be significant for reasons of social equity.

However, the limited fiscal capacity of the country plays a decisive role in shaping social policy solutions, while the existing structural weaknesses of the economy and the labour market along with the fragmented character of the welfare state reduce the potential for the effective implementation of active labour market policies. Due to budgetary constraints, the state promotes mostly selective social policy measures that are justified by the extensive and emergency nature of crisis' social repercussions, but they reduce the coverage of social protection. Thus, selective social policy options introduce new forms of dualism in the labour market without solving the problems of the vulnerable groups. This is getting more accentuated in view of the poor results of active labour market policies in terms of employment and income ability. Subsequently, an additional factor that restricts the effectiveness of active labour market policies is related to their use for substituting the fundamental guarantees of income replacement, due to the inability of the Greek economy to reduce high levels of poverty and income insecurity. Even if the policy documents suggest for a combination of labour market and welfare state solutions, there are doubts that these objectives can be achieved taking into consideration the unfavorable conjuncture. Moreover, these concerns are even more intense because of the restriction of the public character of social policy in view of the required balance between social spending and economic effectiveness and the transfer of competences in the provision of social services in the private sector.

In addition to these difficulties, there are endogenous weaknesses in the implementation of active labour market policies in Greece, which are related with the lack of a long-term, coherent and well-coordinated design of policy interventions in correspondence to the labour needs, the absence of a quality framework and accreditation of skills, as well as the deficiency to ensure the effective use of resources and the sustainability of initiatives. There also the side effects from the implementation of active labour market policies. As we have seen in previous 
sections, a vast array of active interventions has been implemented so far to support employment and social inclusion. Before economic crisis, active labour market policies were selective as they were reserving a preferential treatment for women, young people and unemployed, but they function more as universal employment support programmes. During economic crisis and, mostly after 2012, the selective targeting of the active employment policies was the main answer to the crisis. In the the last quarter of 2014 more targeted and selective active measures have been promoted in favor of the most affected by unemployment and the vulnerable groups by advancing integrated actions of training and counselling services, public works programme, apprenticeships and voucher-based internship scheme for the young unemployed, as well as unemployment assistance for the long-term unemployed. Furthermore, before economic crisis the main side effects of the active labour market programs were mainly related to the high rates of "dead weight", as well as to the low achievement of objectives and the low sustainability of results. On the contrary, the main side effects of active labour market programs during economic crisis are related to the targeting of the programs and the substitution of employers by the beneficiaries to cover their need in labour force.

Nevertheless, the economic crisis revealed the necessity of active labour market policies not separately, but in combination with other welfare state's interventions in order to reduce the substitution of income and support their effectiveness. It seems that actors in Greece are better equipped now with alternative active labour market solutions to counter social crisis. What is needed is to fully exploit other countries' experiences in active labour market policies in combination with social protection measures and to increase expenditure in favor of active labour market policies to combat unemployment and social exclusion. Despite the narrow margins of policy options, there are several challenges for promoting active labour market policies, particularly in a recession, provided that they will not substitute the fundamental guarantees of income replacement and that will be associated with a comprehensive policy of job creation, while preserving the public character and the role of the state that should not be undermined under the pretext of budgetary constraints.

\section{References}


Avram, S., Figari, F., Leventi, C., Levy, H., Navicke, J., Matsaganis, M., Militaru, E., Paulus, A., Rastringina, O. \& Sutherland, H. (2013). "The Distributional Effects of Fiscal Consolidation in Nine Countries", Working Paper EM 2/13, EUROMOD.

Bank of Greece (2014a). Report of the Governor for the year 2013, Athens.

Bank of Greece (2014b). The Chronicle of the Great Crisis: The Bank of Greece 2008-2013, Athens: Bank of Greece, Centre of Culture, Research and Documentation.

Bank of Greece (2015). Monetary Policy 2014-2015, Athens.

Begg, I., Mushövel, F., Niblett, R., Vandenbroucke, F., Rinaldi, D., Wolff, G., Wilson, K., Hüttl, P., Hellström, E. and Kosonen, M. (2015). Redesigning European welfare studies - Ways forward, Germany: Vision Europe Summit.

Carnoy, M. (1979). Can educational policy equalize income distribution in Latin America? England: SAXON HOUSE.

Cedefop (2014a). Vocational education and training in Greece, Short description, Luxembourg: Publications Office of the European Union.

Cercas, A. (2014). Report on Employment and social aspects of the role and operations of the Troika (ECB, Commission and IMF) with regard to euro area programme countries, Brussels: European Parliament.

Cazes, S., Verick, S. \& Heuer, C. (2009). Labour market policies in times of crisis, Geneva: International Labour Office.

Chrysakis, E. (2012). The use of administrative data for the evaluation of labour market policies and programmes: an utopia or a still promising issue for Greece? Peer Review on "Evaluation of Labour Market Policies and Programmes: The use of data-driven analysis", Belgium: ICF GHK Consulting \& CERGE-EI.

Collins, M. (2012). "Responding to the unemployment crisis: what role for active labour market policies?” NERI Working Papers Series NERI WP 2012/No 5.

Contini, B. (2002). Employment performance and labor market segmentation in Europe and USA: preliminary explorations, Italy: University of Torino.

De la Croix, D., Docquier, F., Mainguet, C., Perelman, S. \& Wasmer, E. (2002). Capital Humain et Dualisme sur le Marché du Travail, Belgium: Editions De Boeck Université.

Diadikasia S.A. (2014), "Evaluation Report of the Programme for 2013 under the project Evaluation Consultant during the Implementation (on-going) of the 
Operational Programme Human Resources Development" (in Greek), http://www.epanad.gov.gr.

Dimoulas, K. - Michalopoulou, K. (2008). Active Labour Market Policies. The Case of Integrated Interventions in the Prefectures of Arta, Thesprotia, Preveza, Larissa and Ftiotida, Athens: Labour Institute of Greek General Confederation of Labour (in Greek).

EEO Group (2012). "Study of Redesign of Active Employment Policy's Actions \& Definition of the way of their Evaluation" (in Greek), http://www.epanad.gov.gr.

Emmenegger, P., Kvist, J., Marx, P. and Petersen, K. (2015). "Three Worlds of Welfare Capitalism: The making of a classic", Journal of European Social Policy, 25 (1), pp. 3-13.

Espin-Andersen, G. (1990). The Three Worlds of Welfare Capitalism, Princeton, New Jersey: Princeton University Press.

Espin-Andersen, G. with Gallie, D., Hemerijck, A., Myles, J. (2002). Why we need a New Welfare State, Oxford-New York: Oxford University Press. Greek translation

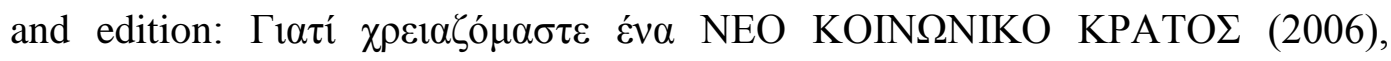

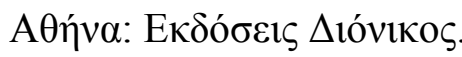

European Commission (2013a). "The Second Economic Adjustment Programme for Greece - Third Review", European Economy Occasional Papers No 159, Brussels: European Commission.

European Commission (2013b). Draft Joint Employment Report accompanying the Communication from the Commission on Annual Growth Survey 2014, COM (2013) 801 final, Brussels, 13 November 2013.

European Commission (2013c). Overview of progress in implementing countryspecific recommendations by Member State, COM (2013) 800 final, Brussels, 13 November 2013.

European Commission (2014a). Market reforms in Italy, Spain, Portugal and Greece, European Economy 5/2014, Brussels: European Commission, Directorate-General for Economic and Financial Affairs.

European Commission (2014b). "The Second Economic Adjustment Programme for Greece - Fourth Review", European Economy Occasional Papers No 192, Brussels: European Commission.

European Commission (2014c). Employment and Social Developments in Europe 2014, Luxembourg: Publications Office of the European Union. 
European Commission (2015a). Active Labour Market Policies. European Semester Thematic Fiche, Brussels: European Commission.

European Commission (2015b). Assessment of the Social Impact of the new Stability Support Programme for Greece, Commission Staff Working Document, Brussels, 19.8.2015, SWD (2015) 162 final.

European Foundation for the Improvement of Living and Working Conditions Eurofound (2010). Financing and operating active labour market programmes during the crisis, Background Paper, Ireland: EUROFOUND.

Ferrera, M. (1996). 'The southern model of welfare in Europe', Journal of European Social Policy, 6: 1, 17-37.

Friends of Europe (2015a). Unequal Europe. Recommendation for a more caring EU, Final report of the High-Level Group on Social Union, Brussels.

Friends of Europe (2015b). Europe's Jobs Policy Shake-up, High level Conference, Brussels.

García Pérez, J. I. \& Osuna, V. (2014). "Dual labour markets and the tenure distribution: Reducing severance pay or introducing a single contract", Labour Economics 29 (2014) 1-13.

Garibaldi, P. \& Taddei, F. (2013). Italy: a dual labour market in transition: Country case study on labour market segmentation, Geneva: International Labour Office.

International Labour Organisation - ILO (2015). An employment-oriented investment strategy for Europe. Geneva: ILO.

International Labour Organisation - ILO (2014). Greece: Productive jobs for Greece. Geneva: ILO.

International Labour Organisation and International Institute for Labour Studies (2011a). Dual Labour Markets with search costs, EC-IILS Joint Discussion Paper Series No 7, The International Institute for Labour Studies (IILS).

International Labour Organisation and International Institute for Labour Studies (2011b). Active labour market policies, search costs and positive fiscal multiplier, EC-IILS Joint Discussion Paper Series No 8, The International Institute for Labour Studies (IILS).

Jessoula, M., Matsaganis, M, Natili, M. (2015). "Strengthening minimum income protection in Southern and Eastern Europe? Pressures from within and from beyond". Paper presented for the $22^{\text {nd }}$ International Conference of Europeanists, Paris, 8-10 July 2015. 
Karamessini, M. (2015). “The Greek Social Model: Towards a Deregulated Labour Market and Residual Social Protection", in Vaughan-Whitehead, D. (ed.), The European Social Model in Crisis. Is Europe Losing its Soul? Geneva, Switzerland/Cheltenham UK: ILO/Edward Elgar.

Karantinos, D., Linardis, A., Mouriki, A., Chrysakis, M., Kostaki, I. (2015). "Study of External Interim Evaluation of the Action Voucher Entry to the Labour Market of the Operational Programme Human Resources Development with MIS code 455372", Athens: National Centre for Social Research (in Greek), http://www.epanad.gov.gr.

Karantinos, D. (2014). An evaluation of the social and employment aspects and challenges in Greece, Brussels: European Parliament.

Karantinos, D., Chrysakis, M., Balourdos, D., Mouriki, A., Soulis, S., Galata, V., Petraki, M. \& Kostaki, I. (2013). Formulation of a strategic development policy framework 2014-2020 for the thematic objectives 8 "Promoting employment and supporting labor mobility", 9 "Promoting social inclusion and combating poverty" and 10 "Investment in education, skills and lifelong learning", Athens: National Centre for Social Research (in Greek).

Kouzis, J. (2001). Industrial relations and European unification, Flexibility and deregulation or upgrading of work? Athens: Labour Institute of Greek General Confederation of Labour (in Greek).

Labour Institute of the Greek General Confederation of Labour (2011). The Greek economy and employment-Yearly Report 2011, Athens (in Greek).

Leclercq, E. (1999). Les théories du marché du travail - La pensée économique contemporaine (4), Paris: Éditions du Seuil.

Leventi, C., Matsaganis, M. (2016). "Estimating the distributional impact of the Greek crisis (2009-2014)”, OECD Economics Department Working Papers, No. 1312, Paris: OECD Publishing.

Maruani, M. \& Reynaud, E. (2004). Sociologie de l'emploi, 4e edition, Paris: La Découverte.

Martin, J.P. \& Grubb D. (2001). "What works and for whom: A review of OECD countries' experiences with active labour market policies", Swedish Economic Policy Review, 8, pp. 9-56.

Matsaganis, M. (2013). The Greek Crisis: Social Impact and Policy Responses, Berlin: Friedrich Ebert Stiftung (in Greek). 
Ministry of Education, Research and Religion (2016). "National Strategic Framework for upgrading Vocational Education and Training and Apprenticeships" (in Greek)

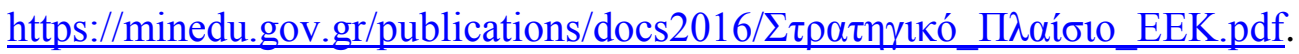

Ministry of Finance (2015). National Reform Programme, Athens, (in Greek).

Ministry of Labour, Social Security and Welfare (2014). Government Employment Council, $1^{\text {st }}$ Meeting on 01.09.2014, Athens: Ministry of Labour (in Greek).

Mitrakos, T. (2014). "Inequality, poverty and social welfare in Greece: distributional effects of austerity”. Working Paper 174, Athens : Bank of Greece (in Greek).

Morrison, C. (1996). La répartition des revenues, Paris: Presses Universitaires de France.

OECD (2013). Economic Survey of Greece 2013, Paris: OECD Publishing.

OECD (2014). Society at a Glance 2014, Highlights: Greece - The crisis and its aftermath, Paris: OECD Publishing.

OECD (2016). OECD Economic Surveys Greece, Paris: OECD Publishing.

Palier, B. and Thelen, K. (2010). "Institutionalizing Dualism: Complementarities and Change in France and Germany", Politics \& Society, 38 (1), pp. 119-148.

Papadopoulos, T. \& Roumpakis, A. (2013). "Familistic welfare capitalism in crisis: social reproduction and anti-social policy in Greece", Journal of International and Comparative Social Policy, 29 (3), pp. 204-220.

Petmesidou, M. \& Papatheodorou, C. (eds.) (2010). Social Reforms and the Changing "Public" - "Private" Mix in Social Welfare, Conference proceedings of the 3nd International Conference of Hellenic Social Policy Association. Athens: Ellinika Grammata (in Greek).

Petmesidou, M. and Guillén, A. (2015). Economic crisis and austerity in Southern Europe: threat or opportunity for a sustainable welfare state? OSE Research Paper No. 18, Bruxelles: European Social Observatory.

Prokou, E. (2011). "The aims of employability and social inclusion / active citizenship in lifelong learning policies in Greece", The Greek Review of Social Research, special issue 136 C', pp. 203-223 (in Greek).

Rueda, D. (2006). "Social Democracy and Active Labour-Market Policies: Insiders, Outsiders and the Politics of Employment Promotion", British Journal of Political Science, 36(3), pp. 385-406. 
Shahidi, F.V. (2015). "Welfare Capitalism in crisis. A Qualitative Comparative Analysis of Labour Market Policy Responses to the Great Recession", Journal of Social Policy, 44 (4), pp. 659-686.

Tremblay, D.-G. (1990). Economie du travail. Les réalités et les approaches théoriques, Québec: Ed. Saint-Martin.

Vlandas, T. (2013). "Mixing apples with oranges? Partisanship and active labour market policies in Europe", Journal of European Social Policy, 23(1), 3-20.

Xiarchogiannopoulou, E. \& Aganidis, P. (2014). The Economic Adjustment Programmes and the resistance of neo-liberal ideas: the experience of Greece and the future of progressive politics, Opinion Article No 14, Athens: Hellenic Foundation for European \& Foreign Policy (in Greek).

Zartaloudis, S. (2014). "The impact of the Fiscal Crisis on Greek and Portuguese Welfare States: Retrenchment before the catch-up?", Social Policy \& Administration, 48 (4), pp. 430-449. 